\title{
The effect of active compound isolated from the leaves of kembang bulan [Tithonia diversifolia (Hemsley) A. Gray] on cell cycle and angiogenesis of WiDr cell line
}

\author{
Hajid Rahmadianto Mardihusodo ${ }^{1 *}$, Mae Sri Hartati Wahyuningsih ${ }^{2}$, Indwiani Astuti ${ }^{2}$ \\ ${ }^{1}$ Postgraduate Program in Biomedical Sciences, ${ }^{2}$ Department of Pharmacology and \\ Therapy, Faculty of Medicine, Universitas Gadjah Mada, Yogyakarta, Indonesia
}

\begin{abstract}
Colorectal cancer is the tenth most common form of malignant tumor of hospital inpatients in Indonesia. Advance approaches in anticancer development is discovery molecular-targeted drugs. Molecular targets for anticancer drug have been identified including genes associated with cell cycle control and angiogenesis. Previously, an active and selective compound against WiDr from Tithonia diversifolia (Hemsley) A. has been isolated. The aim of this study was to evaluate the effect of the isolated active compound from $T$. diversifolia on the WiDr cell cycle and angiogenesis. Isolation of the active compound was performed by preparative thin layer chromatography (TLC) method. WiDr cell cycle was analyzed by flowcytometry using propidium iodide (PI). Antiangiogenesis effect was evaluated by immunocytochemistry method using anti-human VEGF monoclonal antibody. The results showed that the effect of the isolated active compound on the WiDr cell cycle depended on the concentration and the incubation time periods. At concentration of $4 \mu \mathrm{g} / \mathrm{mL}$, it inhibited the WiDr cell cycle SubG1 phase after 36 and 48 hours incubation and G1 phase after 72 hours incubation. While at concentration of $8 \mu \mathrm{g} / \mathrm{mL}$, it clearly inhibited the WiDr cell cycle G1 phase after 36, 48 and 72 hours incubation. Furthermore, the isolated active compound at concentration of $4 \mu \mathrm{g} / \mathrm{mL}$ significantly inhibited the VEGF expression until $47.38 \%$ compared to control. In conclusion, the isolated active compound from $T$. diversifolia inhibited cell cycle and angiogenesis of WiDr cell.
\end{abstract}

\section{ABSTRAK}

Kanker kolorektal merupakan tumor ganas paling umum ke 10 yang dijumpai pada pasien rawat inap di rumah sakit di Indonesia. Pendekatan terkini dalam pengembangan antikanker adalah penemuan obat dengan target kerja di tingkat molekuler. Target molekuler untuk obat antikanker telah diidentifikasi di antaranya gen yang berperan dalam siklus sel dan angiogenesis. Penelitian sebelumnya menunjukkan sebuah senyawa aktif dan selektif terhadap sel WiDr dari Tithonia diversifolia (Hemsley) A. telah berhasil diisolasi. Penelitian ini bertujuan untuk mengkaji pengaruh pemberian senyawa aktif hasil isolasi dari $T$. diversifolia terhadap siklus sel dan angiogenesis sel WiDr. Isolasi senyawa aktif dilakukan dengan kromatografi lapis tipis (KLT) preparatif. Siklus sel WiDr dianalisis dengan flowsitometri menggunakan propidium iodida (PI). Efek angiogenesis dikaji menggunakan metode imunositokimia menggunakan antibodi monoklonal anti-human VEGF. Hasil penelitian menunjukkan efek senyawa aktif hasil isolasi terhadap siklus sel WiDr tergantung pada konsentrasi dan masa inkubasi. Pada konsentrasi $4 \mu \mathrm{g} / \mathrm{mL}$, senyawa ini menghambat siklus sel WiDr fase SubG1 setelah inkubasi 36 dan 48 jam dan fase G1 setelah inkubasi 72 jam.

\footnotetext{
* corresponding author: hajidrahmadianto@gmail.com
} 


\begin{abstract}
Sedangkan pada konsentrasi $8 \mu \mathrm{g} / \mathrm{mL}$, senyawa ini dengan jelas menghambat siklus sel WiDr fase $\mathrm{G} 1$ setelah inkubasi 36, 48 dan 72 jam. Lebih lanjut senyawa aktif hasil isolasi pada konsentrasi pada $4 \mu \mathrm{g} / \mathrm{mL}$ secara nyata menghambat ekspresi VEGF hingga $47.38 \%$ dibandingkan kontrol. Dapat disimpulkan senyawa aktif hasil isolasi dari $T$. diversifolia menghambat siklus sel dan angiogenesis sel WiDr.
\end{abstract}

Keywords: isolated active compound - T. diversifolia - WiDr cells - cell cycle - antiangiogenesis

\section{INTRODUCTION}

Cancer has become a serious health problem in Indonesia. Cancer is the fifth leading cause of death in Indonesia. It was reported that cervical, breast, skin, rectum, nasopharynx, ovary, lymphnode, colon, thyroid and soft tissue cancer are ten types of cancer that most often found among cancer patients. ${ }^{1}$ Colorectal cancer is the third most common form of cancer found in men and the second in women in the world's. The colorectal cancer causes $8 \%$ of cancer death with approximately 608.000 deaths annually. In Indonesia, colorectal cancer is the tenth most common form of malignant tumor of hospital inpatients. ${ }^{3}$

New approaches to anticancer drug development involve the discovery of molecularly targeted anticancer agents having selective of action to cancer cells without toxic to normal cells. ${ }^{4}$ Several molecular targets for anticancer drug discovery and development have been identified including genes associated with cell cycle control and angiogenesis. ${ }^{5} \mathrm{~A}$ wide range of plants have been reported contain compound with cell cycle or angiogenesis modulating properties. Moreover, some plantderived anticancer drugs including taxol, camptothecin and combretastatin are antiangiogenic. ${ }^{5,6}$

Tithonia diversifolia (Hemsley) A. Gray, locally known as kembang bulan, has been reported to have anticancer activity by some authors. Chloroformic extract of T. diversifolia, chloroformic insoluble fraction, as well as benzene-washed insoluble fraction III from the chloroformic extract have been proven to have cytotoxic effect on HeLa cells. ${ }^{7-9}$ Further study, an active compound was isolated and its the cytotoxic effect on HeLa cells was evaluated with an $\mathrm{IC}_{50}$ value of $5.86 \mu \mathrm{g} / \mathrm{mL}$. Moreover this active compound caused apoptosis by increasing p53 expression. ${ }^{10-12}$ Wahyuningsih and Wijayanti ${ }^{13}$ reported that the isolate of $\mathrm{B} 2$ is the most active and selective compound against WiDr cell line with an $\mathrm{IC}_{50}$ value $0.59 \mathrm{ug} / \mathrm{mL}$ and selectivity index of 69.02.

An active compound known as tagitinin $\mathrm{C}$ has been isolated from methanolic extract of $T$. diversifolia and the inhibitory activity against malignant glioblastoma has been reported. ${ }^{14}$ Furthermore, Garcia and Delgado ${ }^{15}$ isolated tagitinin A and tagitinin $\mathrm{C}$ from $T$. diversifolia that exhibited a cytotoxic effect on HCT-15 cells. While Gu et al. ${ }^{16}$ reported that tagitinin $\mathrm{C}$ shows antiproliferation activity on human colon cancer (Col2) cells.

In this study, we evaluated the activity of an active compound isolated from $T$. diversifolia against WiDr cancer cells. The effect of this isolated active compound on WiDr cell cycle and its angiogenesis was also evaluated. 5Fluorouracil was used as positive control in this study due to this anticancer agent is frequently used to treat several types of cancer including colorectal cancer. 
Mardihusodo, The effect of active compound isolated from the leaves of kembang bulan [Tithonia diversifolia (Hemsley) A. Gray] on cell cycle and angiogenesis of WiDr cell line

\section{MATERIALS AND METHODS}

\section{Isolation of the active compound from $T$. divesifolia}

The active compound from $T$. diversifolia leaves was isolated from chloroformic extract in laboratory of Pharmacology and Therapy, Faculty of Medicine, Universitas Gadjah Mada, Yogyakarta. The isolation of the active compound was performed by preparative thin layer chromatography (TLC) method using silica gel $\mathrm{GF}_{254}$ as stationary phase and mixture of benzene and ethyl acetate in the ratio of 2:1 $(\mathrm{v} / \mathrm{v})$ as mobile phase. Visualisation of the bands of the isolated active compound was performed using UV light at 254 and $366 \mathrm{~nm}$. The isolated active compound having similar band or retardation factor (Rf) with the standard compound isolated by Soeprapto ${ }^{8}$ was subjected to isolate and used for further investigation.

\section{Cell culture and cytotoxicity assay}

WiDr cell lines were cultured in culture flask containing containing complete Dulbecco's Modified Eagle's Medium(DMEM) supplemented with $10 \% \mathrm{FBS}$ and $1 \%$ penicillin-streptomycin . Cultures were maintained in $5 \% \mathrm{CO}_{2}$ incubator at $37^{\circ} \mathrm{C}$ and fed every 3 days with complete DMEM. Confluent cells were trypsinized, and harvested cells were used for experiments.

Cytotoxicity of the isolated active compound was evaluated on WiDr cells using the MTT [3-9,4,5-dimethylthiazole-2-yl-2,5diphenyltetrazolium bromide assay]. Cells were distributed in 96-wells microplates at $2 \times 10^{4}$ cells per well in $100 \mathrm{~mL}$ and $100 \mathrm{~mL}$ of complete DMEM were added. The cell cultures were then incubated in $5 \% \mathrm{CO}_{2}$ incubator at $37^{\circ} \mathrm{C}$ for 24 hours. After incubation, the medium was removed and replaced with new complete DMEM containing various concentrations of the isolated active compound tested. The cells culture and the isolated active compound were incubated again in $5 \% \mathrm{CO}_{2}$ incubator at $37^{\circ} \mathrm{C}$ for 24 hours. After the incubation, the medium was removed and the cells were resuspended with DMEM. Ten $10 \mathrm{~mL}$ of $5 \mathrm{mg} / \mathrm{mL}$ MTT was added and then further incubated for 4 hours. The reaction was stopped by adding $100 \mathrm{~mL}$ of $10 \%$ sodium dodecyl sulfate (SDS) in $0.01 \mathrm{~N}$ $\mathrm{HCl}$. Microculture plates were then shaken gently for 5 minutes, covered with aluminium foil and incubated at room temperature overnight. Optical density (OD) of the microculture plates was measured in an ELISA plate reader at $1_{\max } 595 \mathrm{~nm}$. The OD values were directly proportional to the number of viability cells. The OD values of plate in the presence of isolated active compound tested were compared with that of control cultures without isolated active compound tested to obtain cells growth inhibition. Inhibitory Concentration 50\% $\left(\mathrm{IC}_{50}\right)$ values were then determined by probit regression analysis based on the relationship between $\log$ concentrations versus the percentage of cells growth inhibition. 5Fluorouracil was used as positive control.

\section{Cell cycle analysis}

Cells cycle analysis was conducted by flowcytrometry. WiDr cell cultures were distributed onto 24-well plates at density of $5 \mathrm{x}$ $10^{5}$ cells per well and incubated in $5 \% \mathrm{CO}_{2}$ incubator at $37^{\circ} \mathrm{C}$ overnight. After overnight incubation, the WiDr cells culture were treated with $500 \mu \mathrm{L}$ of the isolated active compound tested at 2 different concentrations which were equivalent to the value of $\mathrm{IC}_{50}$ and $2 \mathrm{IC}_{50}$ or 5 fluorouracil for $24,36,48$ and 72 hours. Following after incubation, the cells were collected and harvested. After centrifugation, cell pellets were then washed twice with 500 $\mu \mathrm{L}$ of cold PBS. Cells were then incubated with $400 \mu \mathrm{L}$ of $50 \mu \mathrm{g} / \mathrm{mL}$ propidium iodide reagent 
at $37^{\circ} \mathrm{C}$ for 10 minutes and transferred to flowcytotube. The cells were immediately analyzed by FACS Calibur flowcytometer to evaluate cell cycle profile. Flowcytometric data were analyzed using Cell Quest program to evaluate the cells distribution at each phase of the cell cycle namely the sub $\mathrm{G}_{1}$ (apoptosis), $\mathrm{S}$, $\mathrm{G}_{2} / \mathrm{M}$, and the cells undergoing polyploidy. The cell cycle inhibition was observed by comparing the cells distribution at $\mathrm{G}_{0} / \mathrm{G}_{1}$ and $\mathrm{G}_{2} / \mathrm{M}$ phases of treated and untreated cells.

\section{Antiangiogenesis assay}

Antiangiogenesis activity was analyzed by immunohistochemistry. WiDr cell cultures were distributed onto 24-well plates at density of $5 \mathrm{x}$ $10^{4}$ cells per well and incubated in $5 \% \mathrm{CO}_{2}$ incubator at $37^{\circ} \mathrm{C}$ overnight. After overnight incubation, the WiDr cells culture were treated with $500 \mu \mathrm{L}$ of the isolated active compound tested and 5-fluorouracil at concentrations of 4 and $60 \mu \mathrm{g} / \mathrm{mL}$, respectively and incubated for 15 hours. Following incubation, the medium was removed and the cells were rinsed in $500 \mu \mathrm{L}$ of PBS. The cells were fixed with $300 \mu \mathrm{L}$ methanol and incubated in freezer for 10 minutes. The cells were rinsed three time in PBS and water, respectively. The cells were then blocked with serum blocking solution, incubated with a primary anti-human VEGF monoclonal antibody for 10 minutes and rinsed in PBS. Following incubation, the cells were incubated with a biotinylated universal secondary antibody for 10 minutes and rinsed again in PBS. The cells were incubated with a streptavidine peroxidase for 10 minutes at room temperature, rinsed in
PBS. The cells were then incubated with diamino-benzidine for 10 minutes and rinsed with water. The cells were then dried and coverslipped. All coverslip were examined and evaluated using light microscope with magnification 400 times. The VEGF expression was identified as a brown color of the cytoplasmic cell, while a blue color of cytoplasmic cell indicated no expression of the VEGF.

\section{Stastitical analysis}

Data were presented as the mean \pm standard error of the mean (SEM). Statistical comparisons were performed using analysis of variance (ANOVA) continued by Tukey posthoc test. The differences between groups were considered significant at a value of $<0.05$. Protocol of the study was approved by the the Medical and Health Research Ethic Committee, Faculty of Medicine, Universitas Gadjah Mada, Yogyakarta.

\section{RESULTS}

\section{Isolation active compound from the leaves of T. diversifolia}

The TLC profile of the active compund isolated from the leaves of $T$. diversifolia is presented in FIGURE 1. The isolated active compound shows a single band with purple color on silica gel GF254 using visualisation at UV $254 \mathrm{~nm}$. This isolated active compound has a similar band to isolated standard compound with Rf value of 0.3 . Moreover, both of the isolated active compound and isolated standard compound are not observed using visualisation at UV $366 \mathrm{~nm}$. 
Mardihusodo, The effect of active compound isolated from the leaves of kembang bulan

[Tithonia diversifolia (Hemsley) A. Gray] on cell cycle and angiogenesis of WiDr cell line

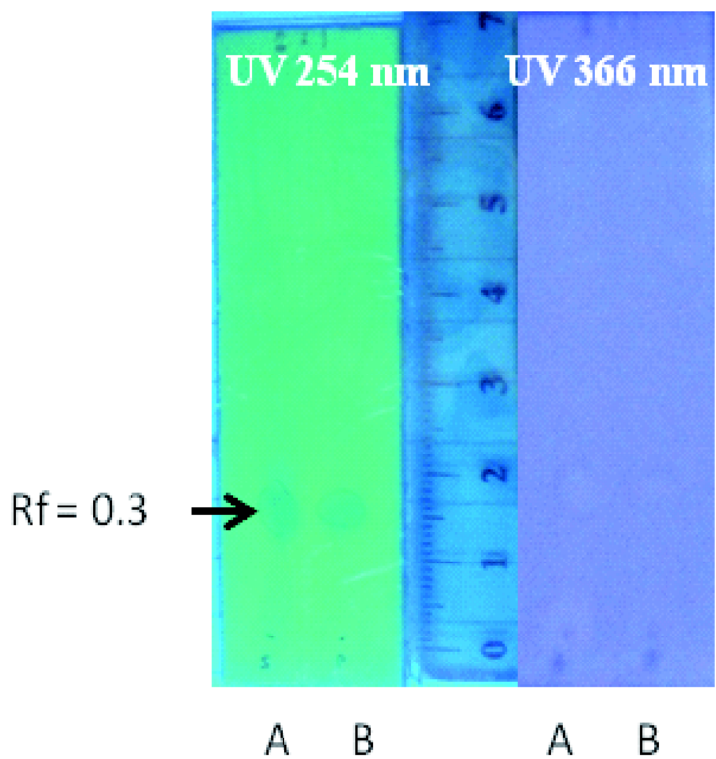

FIGURE 1. The TLC profile of the isolated active compound isolated from $T$. diversifolia using silica gel $\mathrm{GF}_{254}$ as stationary phase and mixture of benzene and ethyl acetate in the ratio of $2: 1(\mathrm{v} / \mathrm{v})$ as mobile phase and visualisation using UV 254 and 366 nm. A. Standard compound; B. Sample.

\section{Cytotoxicity of the isolated active compound}

The growth inhibition of WiDr cells in vitro after incubation with the isolated active compound isolated from $T$. diversifolia leaves and 5-FU in various different concentrations after 24 hours incubation is presented in TABLE 1. This study showed that the isolated active compound and 5-FU inhibit the WiDr cells growth in a dose-dependent manner. Furthermore, the probit regression analysis resulted the $\mathrm{IC}_{50}$ value of the isolated active compound of $3.75 \mu \mathrm{g} / \mathrm{mL}$. While the $\mathrm{IC}_{50}$ of the 5-FU could not be determined due to in the highest concentration $(40 \mu \mathrm{g} / \mathrm{mL})$, the growth inhibition did not reach 50\% (10.45\%). Therefore, it was assumed that the $\mathrm{IC}_{50}$ of 5-FU is more than $40 \mu \mathrm{g} / \mathrm{mL}$. This results indicated that the isolated active compound is more active than 5-FU against WiDr cells.

TABLE 1. The growth inhibition of WiDr cells (\%) after 24 hours incubation with the isolated active compound and $5-\mathrm{FU}$ and its $\mathrm{IC}_{50}$ value $(\mu \mathrm{g} / \mathrm{mL})$

\begin{tabular}{|c|c|c|c|}
\hline Compound & Dose $(\mu \mathrm{g} / \mathrm{mL})$ & $\begin{array}{l}\text { Growth inhibition } \\
(\%)\end{array}$ & $\mathrm{IC}_{50}(\mu \mathrm{g} / \mathrm{mL})$ \\
\hline \multirow{8}{*}{$\begin{array}{l}\text { Isolated active } \\
\text { compound }\end{array}$} & 0.039 & -14.27 & \multirow{8}{*}{3.75} \\
\hline & 0.078 & -18.54 & \\
\hline & 0.15625 & -16.40 & \\
\hline & 0.3125 & -2.25 & \\
\hline & 0.625 & -12.70 & \\
\hline & 1.25 & 7.19 & \\
\hline & 2.5 & 24.83 & \\
\hline & 5 & 67.53 & \\
\hline \multirow{8}{*}{$\begin{array}{l}\text { Standard } \\
\text { compound }\end{array}$} & 0.312 & -11.01 & \multirow{8}{*}{$>40$} \\
\hline & 0.625 & -13.48 & \\
\hline & 1.25 & 0.30 & \\
\hline & 2.5 & -1.69 & \\
\hline & 5 & -2.36 & \\
\hline & 10 & 5.00 & \\
\hline & 20 & 18.31 & \\
\hline & 40 & 10.45 & \\
\hline
\end{tabular}




\section{The effect of isolated active compound on cell cycle}

The effect of the isolated active compound and 5-FU as an anticancer control on the WiDr cell cycle were evaluated by flowcytometry. FIGURE 2 and FIGURE 3 show the WiDr cell cycle profile after incubation with the isolated active compound and 5-FU, respectively. Two different concentrations of the isolated active compound (4 and $8 \mu \mathrm{g} / \mathrm{mL}$ ) and 5-FU (60 and $120 \mu \mathrm{g} / \mathrm{L})$ and 4 different of the incubation time periods (24, 36, 48 and 72 hours) were applied in this study. FIGURE 2 shows that the effect of the isolated active compound on the WiDr cell cycle depend on the concentration and the incubation time periods. The isolated active compound at concentration of $4 \mu \mathrm{g} / \mathrm{mL}$ inhibited the WiDr cell cycle SubG1 phase after 36 and 48 hours incubation and G1 phase after 72 hours incubation. While the isolated active compound at concentratin of $8 \mu \mathrm{g} / \mathrm{mL}$ clearly inhibited the WiDr cell cycle G1 phase after 36,48 and 72 hours incubation. Moreover, the inhibition of the WiDr cell cycle $\mathrm{S}$ and G2/M phases were also observed after 48 hours incubation.

A different results on the WiDr cell cycle was observed after incubation with 5-FU (FIGURE 3). 5-Fluorouracil at concentration of 60 and $120 \mu \mathrm{g} / \mathrm{mL}$ clearly inhibited the WiDr cell cycle G1, S and G2/M phases after 72 hours incubation. While after 48 hours incubation in the both concentration, the inhibition of cell cycle was just observed on $\mathrm{S}$ and $\mathrm{G} 2 / \mathrm{M}$ phases.
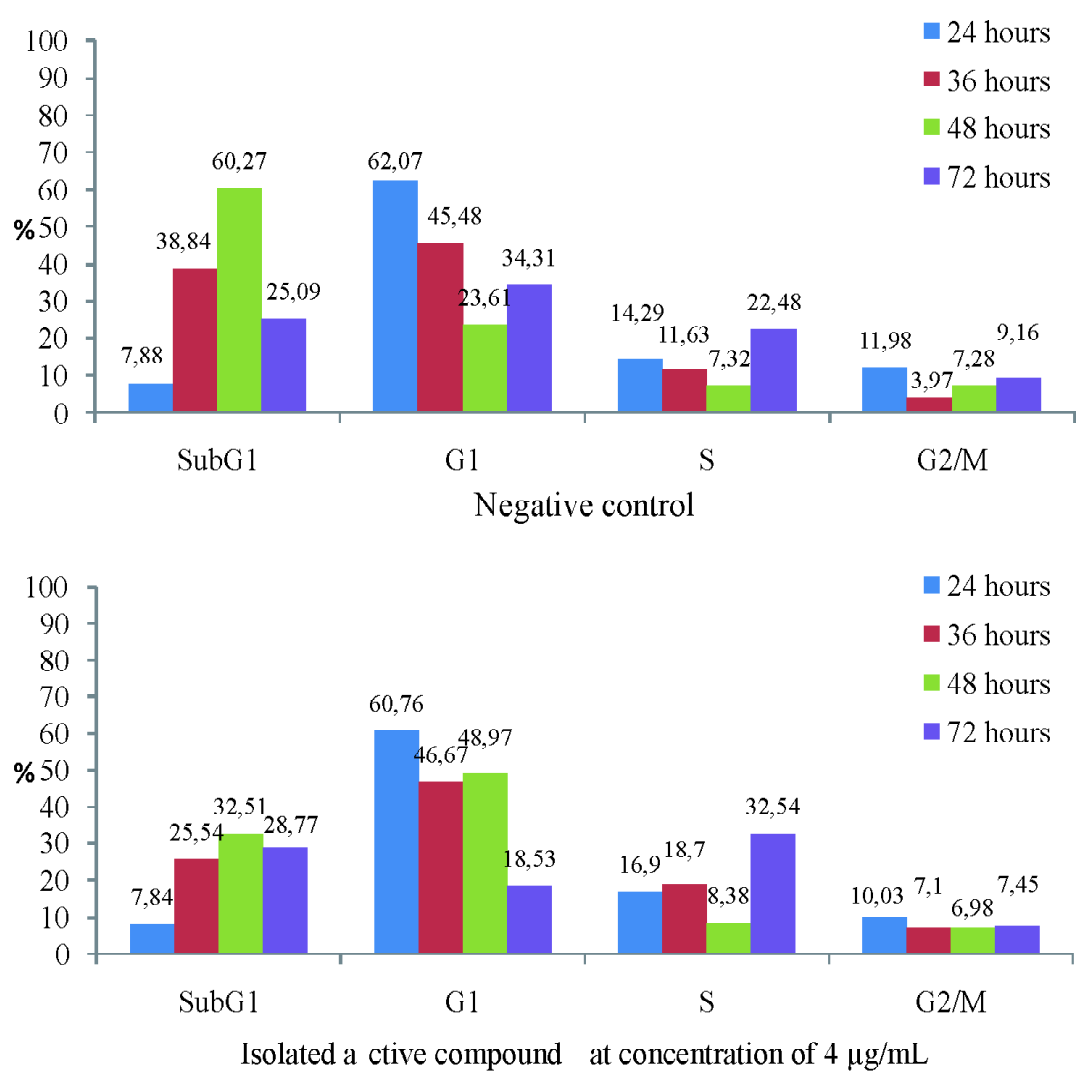

FIGURE 2. The WiDr cell cycle profile after incubation with the isolated active compound at concentration of 4 and $8 \mu \mathrm{g} / \mathrm{mL}$ for 24,36 and 48 hours. 
Mardihusodo, The effect of active compound isolated from the leaves of kembang bulan

[Tithonia diversifolia (Hemsley) A. Gray] on cell cycle and angiogenesis of WiDr cell line

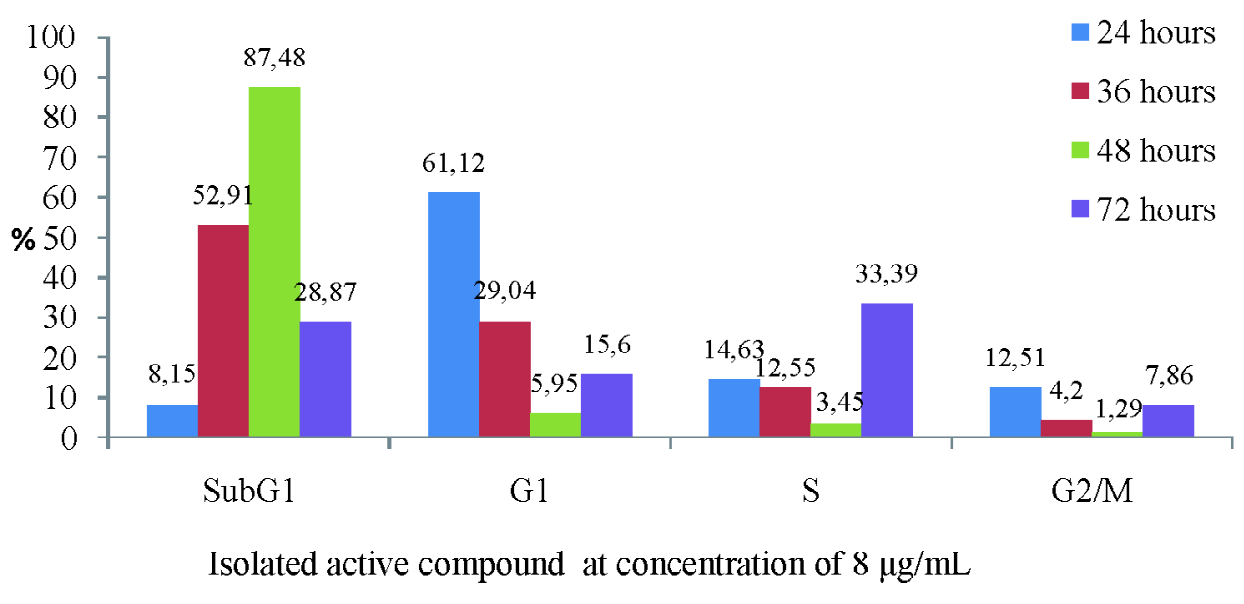

FIGURE 2. The WiDr cell cycle profile after incubation with the isolated active compound at concentration of 4 and $8 \mu \mathrm{g} / \mathrm{mL}$ for 24,36 and 48 hours.
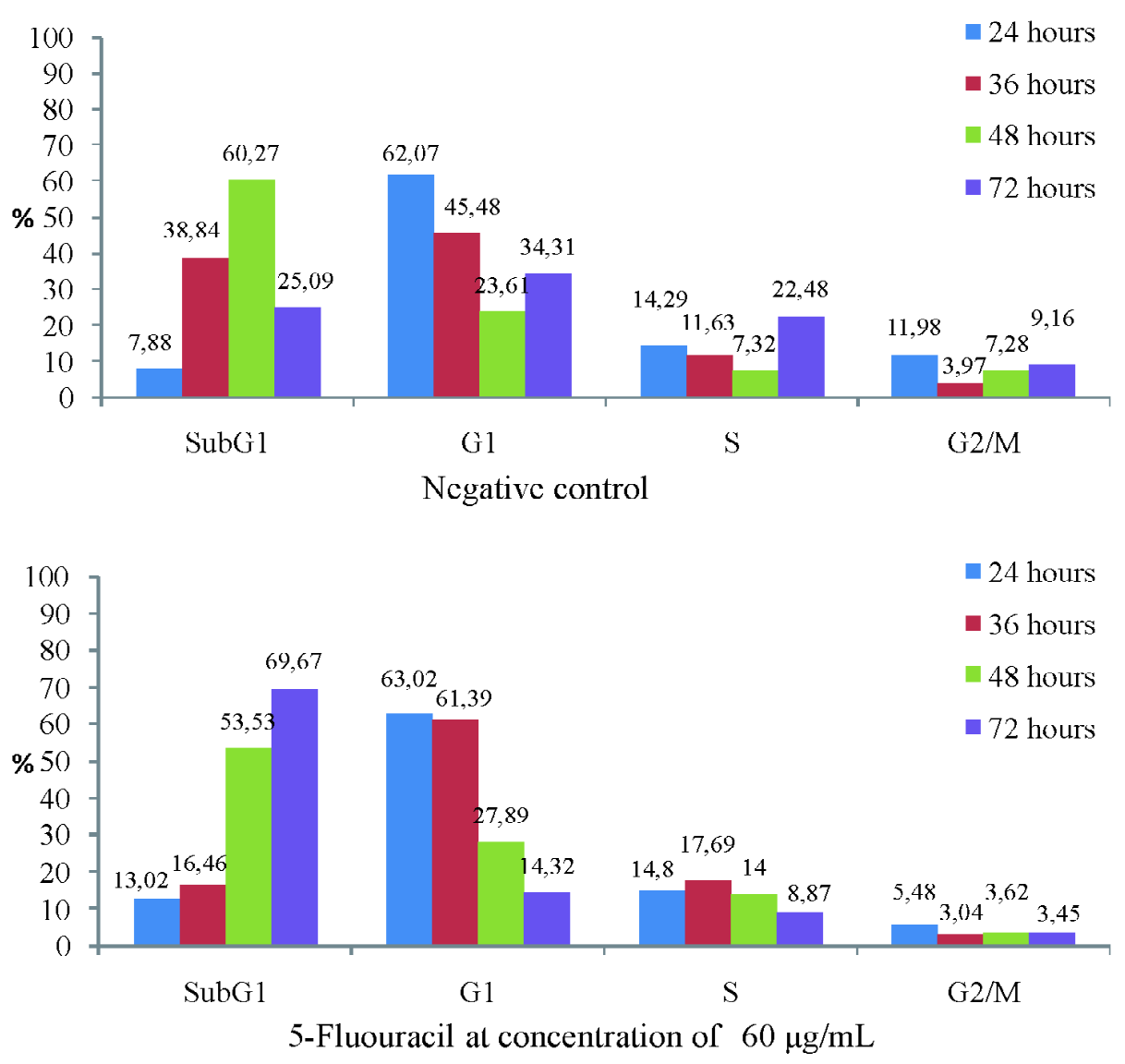

FIGURE 3. The WiDr cell cycle profile after incubation with the 5-FU at concentration of 4 and $8 \mu \mathrm{g} / \mathrm{mL}$ for 24,36 and 48 hours. 


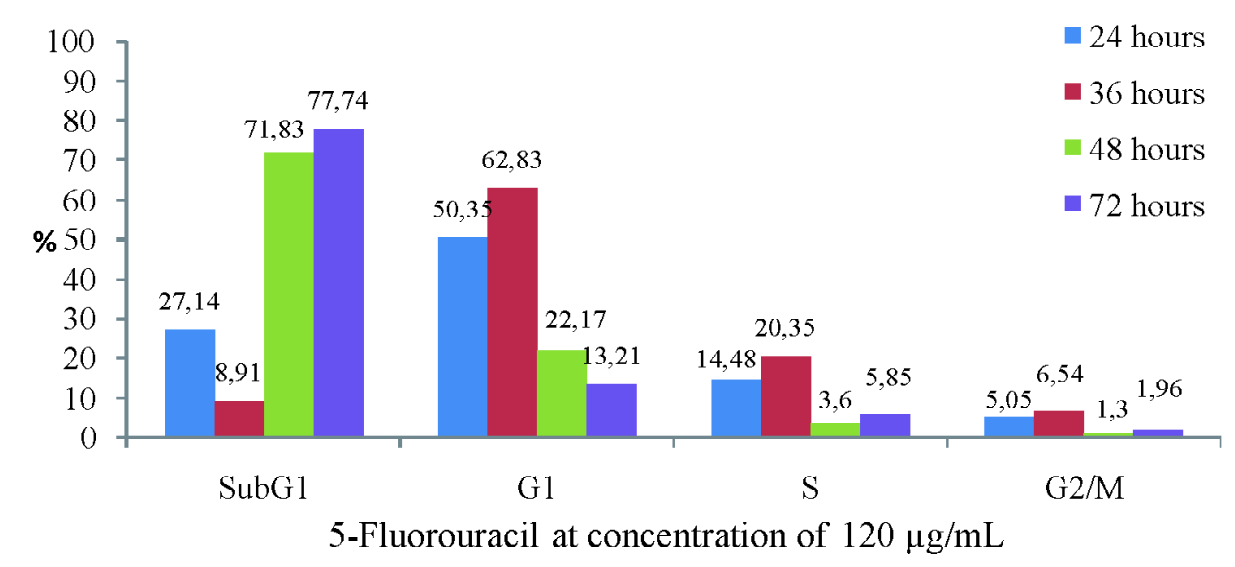

FIGURE 3. The WiDr cell cycle profile after incubation with the 5-FU at concentration of 4 and $8 \mu \mathrm{g} / \mathrm{mL}$ for 24,36 and 48 hours.

\section{The antiangiogenesis effect of the isolated active compound}

An example of VEGF expression in WiDr cells after incubation with the isolated active compound is shown in FIGURE 4. The positive VEGF expression was identified as a brown color of the cell cytoplasma (arrow heads).

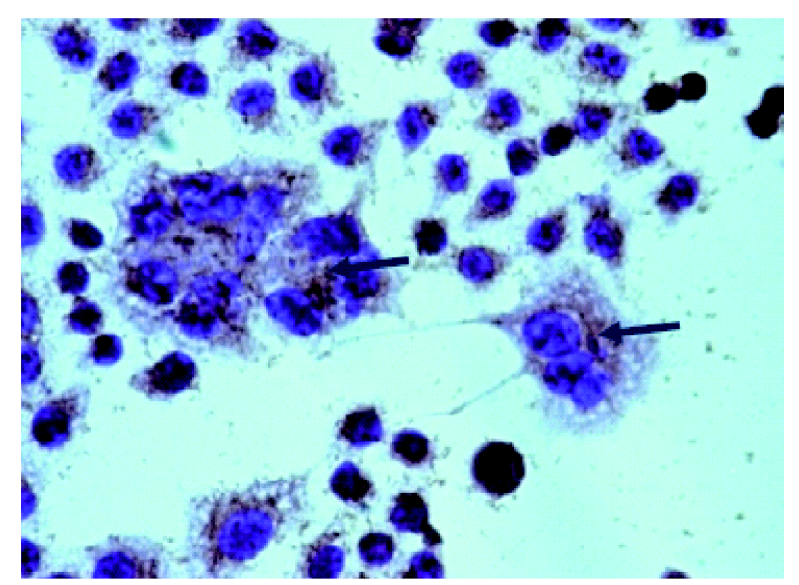

FIGURE 4. VEGF expression in WiDr cells after incubation with the isolated active compound. Positive expression is shown by brown staining (arrow heads). Magnification of 400x.

The percentage of VEGF expression in WiDr cells after incubation with the isolated active compound and 5-FU is presented in
FIGURE 5. The percentage of the VEGF expression after incubation with the isolated active compound at concentration of $4 \mu \mathrm{g} / \mathrm{mL}$ (3.31\%) and 5-FU at concentration $60 \mu \mathrm{g} / \mathrm{mL}$ $(3.75 \%)$ were significantly lower than control $(6.29 \%)(p<0.05)$. It indicates that the isolated active compound and 5-FU exhibit antiangiogenesis againts WiDr cells.

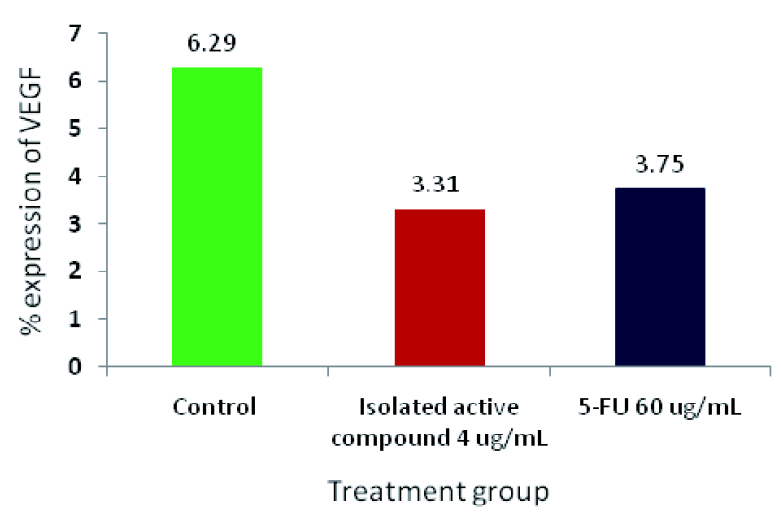

FIGURE 5. Percentage of VEGF expression in WiDr cells after incubation with the isolated active compound and 5-FU

\section{DISCUSSION}

In this study an active compound has been isolated from $T$. diversifolia. This compound may have the same chemical structure with the 
active compound previously isolated by Soeparto ${ }^{10}$ as indicated by the same Rf value $(0.3)$ and the same band using visualisation at UV $254 \mathrm{~nm}$. Furthermore, this active compound is suggested as tagitinin $C(1 \beta, 2 \alpha$-epoxytaginin C) that previously isolated by Liao et al. ${ }^{14}$

The cytotoxicity testing showed that the isolated active compound has potential cytotoxic activity against $\mathrm{WiDr}$ cell line with an $\mathrm{IC}_{50}$ value of $3.75 \mu \mathrm{g} / \mathrm{mL}$. This cytotoxic activity of this isolated active compound is higher than 5-FU ( $>40 \mu \mathrm{g} / \mathrm{mL}$ ), as positive control, indicating that the isolated active compound is more active against WiDr cell line (TABLE 1).

The effect of the isolated active compound on cell cycle of WiDr cell indicated that this compound inhibited non specifically on the cell cycle (FIGURE 2). Some of anticancer agents include alkylating agent, cisplatin, procarbazine and nitrosourea are reported to inhibit non specifically on the cell cycle. ${ }^{17}$ These agents normally have a linear dose-response curve. ${ }^{18}$ In contrast, the anticancer agents that specifically inbibit on cell cycle does not show a linier doseresponse curve.

The inhibition effect of the isolated active compound on cell cycles of WiDr cell may be caused its sesquiterpene lactones skeleton. It was resported that the sesquiterpene lactones isolated from $T$. diversifolia can inhibit NF-kB activity that have an important role in the cell cycle. ${ }^{19}$ The sesquiterpene lactones is considered as an unsaturated carbonyl structure $\alpha, \beta$ which has electrophilic properties and can rapidly interact with protein or DNA molecules. This interaction can cause DNA damage and activate checkpoint of the cell cycle which is an important mechanism of the inhibition of tumor growth. ${ }^{20,21}$

This study also showed that the inhibition profile of WiDr cell cycle of the isolated active compound was different compared to 5-FU. The isolated active compound inhibited non specifically on the cell cycle include all of the WiDr cell cycle phases, while 5-FU clearly inhibited the G1, S and G2/M phases especially after 72 hours incubation (FIGURE 3). The effect of 5-FU on the WiDr cell cycle has been reported by some authors. It is well accepted that 5-FU inhibits the cancer cell cycle $\mathrm{S}$ phase. ${ }^{18,22}$ However, Septisetyani ${ }^{23}$ and Ikawati $^{24}$ showed that 5 -FU inhibits WiDr cell cycle in time-dependent manner. The 5-FU inhibits WiDr cell cycle G1 phase after 24 and 26 hours incubation, however after 48 and 72 hours incubation the inhibition was observed on cell cycle subG1 phase.

Some factors can influence the cell cycle profile using flowcytometry analysis include: 1) characteristic of the cell cycle; 2 ) incubation time period; 3) preparation time of cell; 4) method of cell viability evaluation; 5) quality and concentration of reagents used in staining; and 6) skills for staining techniques.

The VEGF expression on WiDr cell after incubation with the isolated active compound and 5-FU were significantly lower compared to control $(p<0.05)$ showing that the isolated active compound and 5-FU exhibit antiangiogenesis. Moreover, the effect of the isolated active compound at concentration of $4 \mu \mathrm{g} / \mathrm{mL}$ was comparable to the effect of $5-\mathrm{FU}$ at concentration of $60 \mu \mathrm{g} / \mathrm{mL}$ (FIGURE 5).

The mechanism of action of the isolated active compound is suggested similar to three sesquiterpene lactones i.e. as diversifolin, diversifolin and methyl eter and tirotundin isolated from $T$. diversifolia by Rungeler et al. ${ }^{20}$ These sesquiterpene lactones have been reported to inhibit NF- $\kappa B$ activity inhibition has been proven. NF- $\kappa \mathrm{B}$ is a protein composing subunit p50 and p65 that play critical roles in inflammation, immunity, cell proliferation, differentiation, and survival. ${ }^{21}$ Sesquiterpene lactoones group are reported to inhibit NF-kB trascription by alkylation on cysteine residue p65 (Cys 38). ${ }^{25}$ 


\section{CONCLUSION}

The active compound isolated from the leaves of kembang bulan ( $T$. diversifolia) inhibits nonspecifically of WiDr cell cycle. In addition, the isolated active compound inhibits the VEGF expression of the WiDr cell.

\section{ACKNOWLEDGEMENTS}

This study was funded by Community Funds of Faculty of Medicine, Universitas Gadjah Mada, Yogyakarta through Junior Lecture Grant.

\section{REFERENCES}

1. Aziz MF. Gynecological cancer in Indonesia. J Gynecol Oncol. 2009; 20(1):8-10.

2. Anonim. Colorectal cancer incidence and mortality worldwide in 2008 summary. 2008. [Accessed Jan 8, 2011] Available from: http:// globocan.iarc.fr/factsheets/cancers/colorectal. asp

3. Anonim. Profil Kesehatan Indonesia 2008. Jakarta: Departemen Kesehatan RI. 2009.

4. Gali-Muhtasib H. Cyclin-dependent kinase inhibitors from natural sources: recent advances and future prospect for cancer treatment. In: Khan MTH, Ather A. (Eds.): Lead molecules from natural products. Amsterdam: Elsevier B.V. 2006; 155-67.

5. Suggit $M$ and Bibby MC. 50 years of preclinical anticancer drug screening: empirical to targetdriven approaches. Clin Cancer Res. 2005;11:97181.

6. Fan TP, Yeh JC, Leung KW, Yue PYK, Wong RNS. Angiogenesis: from plants to blood vessels. Trends Pharmcol Sci. 2006; 27(6): 298-309.

7. Wicaksono AS. Efek sitotoksik ekstrak metanol dan ektrak kloroform daun kembang bulan ( $T$. diversifolia) terhadap sel hela in vitro [Skripsi]. Yogyakarta: Fakultas Kedokteran Universitas Gadjah Mada. 2007.

8. Saputra F. Uji sitotoksik senyawa hasil partisi ekstrak kloroform daun kembang bulan ( $T$. diversifolia) terhadap kultur sel hela secara in vitro [Skripsi]. Yogyakarta: Fakultas Kedokteran Universitas Gadjah Mada. 2008.

9. Duana Y. Efek sitotoksik in vitro fraksi tidak larut wash benzene dari ekstrak kloroform daun kembang bulan ( $T$. diversifolia) pada sel hela [Skripsi]. Yogyakarta: Fakultas Kedokteran Universitas Gadjah Mada. 2008.

10. Soeparto A. Pemurnian isolat aktif ( $T$. diversifolia) dan uji sitotoksiknya terhadap sel hela in vitro [Skripsi]. Yogyakarta: Fakultas Kedokteran Universitas Gadjah Mada. 2010.

11. Rossila AB. Pengaruh senyawa isolat aktif daun kembang bulan ( $T$. diversifolia) terhadap apoptosis sel hela dengan pengecetan HOECHST 33342 [Skripsi]. Yogyakarta: Fakultas Kedokteran Universitas Gadjah Mada. 2010.

12. Mandela W. Pengaruh senyawa isolat aktif daun kembang bulan (T. diversifolia) terhadap ekspresi protein p53 pada sel hela dengan metode immunohistokimia [Skripsi]. Yogyakarta: Fakultas Kedokteran Universitas Gadjah Mada. 2010.

13. Wahyuningsih MSH, Wijayanti MA. Isolasi, identifikasi senyawa antikanker dari fraksi aktif Tithonia diversifolia (Hemsley) A. Gray, selektivitas dan mekanisme apoptosis secara in vitro. Laporan Akhir Penelitian Riset Pembinaan Iptek Kedokteran. Yogyakarta: Fakultas Kedokteran Universitas Gadjah Mada. 2009.

14. Liao MH, Lin WC, Wen HC, Pu HF. Tithonia diversifolia and its main active component tagitinin $\mathrm{C}$ induce survivin inhibition and $\mathrm{G} 2 / \mathrm{M}$ arrest in human malignant glioblastoma cells. Fitoterapia. 2011; 82(3):331-41.

15. Garcia A, Delgado G. Constituent from Tithonia diversifolia stereochemical revision of $2 \mathrm{a}-$ hydroxytirorundin. J Mex Chem Soc. 2006; 50(4):180-83.

16. Gu JQ, Gills JJ, Park EJ, Mata-Greenwood E, Hawthorne ME, Axelrod F, et al. Sesquiterpenes from Tithonia diversifolia with potential cancer chemopreventive activity. J Nat Prod. 2002; 65:532-6.

17. Brunton LL, Parker K. Chemotherapy of neoplastic disease. In: Brunton LL, Parker K. (Eds.). Goodman \& Gilman's Manual of Pharmacology and Therapeutics. New York: McGraw Hill. 2008.

18. Page R, Takimoto C. Principles of chemotherapy. In: Pazdur R, Coia LR, Hoskins WJ, Wagman LD. (Eds.): Cancer Management: A Multidisciplinary Approach. New York: The Oncology Group. 2003.

19. Rungeler P, Lyss G, Castro V, Mora G, Pahl HL, Merfort I. Study of three sesquiterpene lactones from Thitonia diversifolia on their antiinflammatory activity using the transcription 
factor NF-Kappa B and enzymes of the arachidonic acid pathway as a target. Planta Med. 1998; 64(7):588-93.

20. Rungeler P, Castro V, Mora G, Goren N, Vichnewski W, Pahl HL, et al. Inhibition of transcription factor of NF-kappaB by sesquiterpene lactones: a proposed molecular mechanism of action. Bioorg Med Chem. 1999; 7(11):234352 .

21. Motoyama N, Naka K. DNA damage tumor supressor genes and genomic instability. Curr Opin Genet Dev. 2004; 14(1):11-6.

22. Airley R. Cancer chemoterapy basic science to the clinic. West Sussex: John Wiley \& Sons Ltd. 2009.
23. Septisetyani EP. Aktivitas sitotoksik pentagamavunon-1 tunggal dan kombinasi dengan 5fluorouracil pada sel kanker kolon WiDr [Tesis]. Yogyakarta: Program Pascasarjana UGM. 2008.

24. Ikawati M. Modulasi daur sel dan pemacuan apoptosis pada sel kanker kolon WiDr oleh perlakuan tunggal pentagamavunon-0 dan kombinasinya dengan 5-Fluorouracil [Tesis]. Yogyakarta: Program Pascasarjana Universitas Gadjah Mada. 2008.

25. Garcia-Pineres AJ, Castro V, Mora G, Schmidt TJ, Strunck E, Pahl HL, et al. Cysteine 38 in p65/NFkappaB plays a crucial role in DNA binding inhibition by sesquiterpene lactones. J Biol Chem. 2001; 276(43):39713-20. 